\title{
Guidelines in health clubs and their role in reducing injuries .
}

\author{
Prof: Elham Ismail Shalaby \\ Prof. Hanan Ali Hassanein \\ Dr. Alia Fekhry
}

Researcher / Yara Fawzi Mohammed

Health clubs are considered one of the most important places

for playing sports in Egypt in the current period, as they witnessed a remarkable development in terms of capabilities, sports equipment and tools, which led to an increase in demand by individuals who seek to improve a healthy life or obtain a consistently good strength or who practice sports Permanently and continuously.

As a result of the increasing prevalence of health and sports culture among individuals all over the world, it has become the practice of sports training of sports tasks for individuals, but in a proper and appropriate form for the health condition and personal needs, which does not affect the body negatively and exposes it to injuries.

And the world has witnessed a rapid and significant transformation in the manufacture of sports equipment within health clubs. A health club is a facility or a place where a group of sports activities are practiced for the purpose of health promotion, and it is a place equipped with physical and health activities after it for the purpose of advancing the physical, health and psychological aspects of By providing activities to a large number of citizens with health needs. $(2: 13)$

Health clubs are a place that includes the following activities:

1-Aerobic: It is aerobic exercises through the musical rhythm for the purpose of improving the physical level, as well as maintaining the .public and private fitness of the individual

2-Physical fitness: It is the performance of sports exercises that are given for the purpose of raising the level of efficiency of the body's systems

3-Weight loss: It is an activity that has become a major and essential part of the health club's activities to attract many people, as the 
trainee is subject to a regulated diet and movement program by the specialists.

4-Gyms equipment: It is the use of devices and equipment for the purpose of maintaining physical fitness and also as a treatment for some medical conditions.

5-Sauna: One of the activities of the health club and its main components and used for the purpose of physical recovery, as well as helping to lose weight by raising the body temperature.

6-Steam: also one of the main components of the health club, and is used for the purpose of physical recovery.

7-Massage: It is one of the important and required activities and is used to stimulate blood circulation and improve the physical condition as a result of the disposal of lactic stored in the body.

8-Jacuzzi: It is the use of bursts of water currents on the body and is for the purpose of relaxation.

9-Wax sessions: It has been used recently for the purpose of losing weight, and is placed on the body in a certain way and for a specific period to reduce large amounts of water stored in the body.

10-Sports rehabilitation: One of the services provided by the health club is sports rehabilitation programs for sports injuries and after (16-14:2) surgeries.

And each of these sections contains many devices and tools that should be used correctly, so as not to negatively affect the strength or .growth of the muscles. For frequent health clubs

From here, we should consider the design and equipping of health club halls and departments through:

1-Flooring: Hall floors must be equipped with a material that allows shock absorbers to reduce pressure on the knee ligaments, where they are safe on the joints of the body and also prevent injuries.

2-Walls: The ratio of walls and columns in the hall must be small in order to allow the space to expand, which helps to place the devices comfortably, as well as allowing the presence of ventilation holes to renew the air continuously. 
3-Ceilings: They must be of a suitable height to allow the exercises to be performed, and the lighting in them shall be proportional and equal.

4-Sports equipment and devices: They should be distinguished by quality upon selection, and they should provide safety and security factors, and provide continuous maintenance during the year.

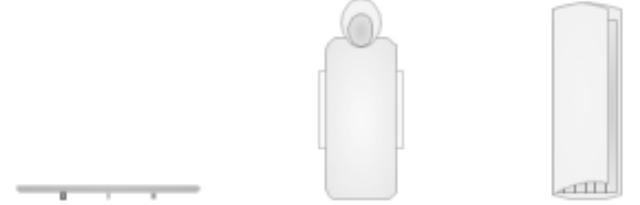

BAletBar

Massage Tade

TarringBed
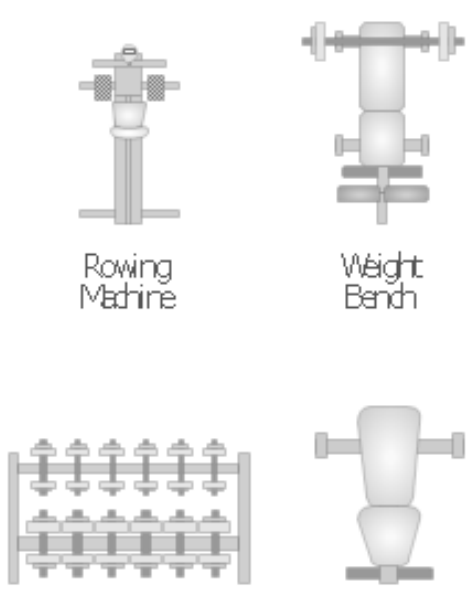

Dumbbal radk
Rowing

Medrine

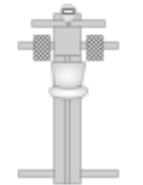

$$
\begin{aligned}
& \text { Meigt } \\
& \text { Bendh }
\end{aligned}
$$

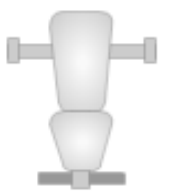

Mutipurpose bend?

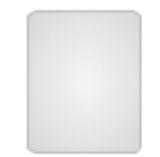

Mat

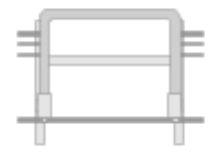

Self spotting

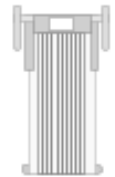

Treadrill

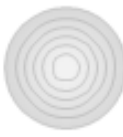

Exarje

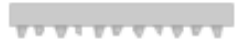

Cimbingwal

Dumbtoel

(1) Figure

\section{Sports equipment available in health clubs}

5-Good organization of health club departments: It means good design of health club departments without causing chaos.

6-Clarification means: The clarification aims to know how to use the equipment in the absence of the trainer from the equipment hall or any of the health club departments, where the recipient helps to perform the exercises properly, so it must be available and clearly and you avoid entering into the details Not important.(5)

The availability of indicative signs (clarification) aims to communicate information and how to deal with sports equipment and warnings that should be avoided, as well as the clarity of their location. (6) 


\section{The importance of health signs:}

Good use of benchmarks helps to achieve the desired goals of exercises using sports equipment:

1-Increasing the opportunity for positive participation by health club visitors.

2-It provides time and effort for the frequency to easily explain how to use the devices.

3-The desired goal was achieved by using the alternating devices.

4-It helps to reduce the occurrence of injuries through the proper use of sports equipment. (7)

\section{The causes of sports injuries:}

There are external factors and internal factors that are interconnected and are a cause of injuries, and sometimes some of these factors are a cause of injuries, and sometimes they are a condition for their appearance, and external factors often lead to changes in the body, and this in turn provides an opportunity for internal factors that end In turn, the injury occurs. (5:85)

\section{External factors that cause injury :}

\section{First: poor organization and training method:}

Its percentage is (30-60\%) of sports injuries. Related to these two factors is the failure to observe the basic guiding principles of education on the part of the trainer, and the most important of these principles are:

-Regular training.

-A gradual increase in physical exertion.

-Mastery and sequence of motor performance.

-The practitioner's individual training process.

Among the most important manifestations of a breach of training rules and poor organization leading to injury are: 
1-Rushing in the exercises, the continuous practice of violent training, and the lack of appropriate means before and after training to renew and revitalize the functional condition of the body (sports massage positive reluctance comfort).

2-Misjudgment of the organized work on the technical side and the incorporation of some exercises that the practitioner is not ready for, whether due to his lack of athletic ability or due to exhaustion in previous training, or the lack or misuse of safety and security precautions.

3-The lack or bad warm-up (heating) and lack of progression in skills, and preparation for the athletic effort to reach the optimum level of fitness, so the deficiency is at the expense of the health and safety of the player and his injury, and that proper physical preparation is a guarantee, security and protection from Incidence occurs. (4:96)

\section{Second: Defects in organizing exercises:}

of sports injuries cases, and these faults are And it represents (4-8\%) represented by:

1-Follow the wrong instructions for training, as well as insurance rules and wrong planning for the training program, and not to implement them.

2-The poor distribution of athletes and the persistence in the large number of them, or the number of spectators in the places of training are a cause of sports injuries.

3-Not taking into account the individual characteristics of the player in terms of efficiency and aptitude in terms of age, weight and gender. $(4: 63)$

\section{Third: Violation of laws and security conditions:}

And it represents(15-25\%) of sports injuries, and it means the condition of stadiums, the places in which sports are practiced, and things related to athletes such as clothes and shoes.

The most important manifestations of a breach of security laws and conditions:

1-Poor quality of sports equipment and equipment. 
2-Poor preparation of devices, equipment, playing fields, etc., for training and competitions.

3-The mismatch of sportswear with the characteristics of the game practiced by the athlete and their suitability to the surrounding climatic conditions, that shoe that does not meet the required conditions and the non-use of defensive tools such as a dental protector in boxing sport.(5:85)

\section{Research objective:}

Guidelines in health clubs and their role in reducing injuries.

\section{Research questions:}

1-Does the availability of indicative signs (health illustrations) in health clubs reduce the rates of injuries for the undecided?

Research procedures:

\section{Research Methodology}

The researcher used the descriptive method for its suitability to the nature of the research.

\section{Research community:}

Some frequencies on private health clubs in Giza Governorate

The research sample:

The basic sample:

The sample was chosen from a number of female practitioners on health clubs intentionally, and the number has reached (50) practitioners on health clubs.

\section{Survey sample:}

were chosen from of female practitioners the private health clubs (15)

\section{Data collection methods:}

1-Books and scientific references related to the research topic: 
The researcher reviewed the Arab and foreign references and reference studies related to the research topic, and the extent of their use in collecting data.

The questionnaire "Guidelines in health clubs and their role in reducing injuries" designed by the researcher.

The researcher assisted in preparing the questionnaire form with a number of sources that benefited from it in defining and formulating the questionnaire phrases / the sources were as follows:

-Previous studies and research related to the research topic.

-Records and documents related to the research topic

Scientific steps to build the questionnaire:

The researcher designed the questionnaire form to apply it to the sample under study (exploratory, basic), and the main axes of the questionnaire were determined in the light of the research goal and also the phrases under each axis were set by following the following steps:

-Theoretical readings of the scientific references for the sports coach and his role.

-Personal interview where the researcher conducted some personal interviews with a group of academic experts to complete the questionnaire form.

-The personal experience of the researcher through her work as a coach at the private health clubs.

Scientific transactions for questionnaire:

First: honesty: 


\section{1-The content is validated by the arbitrators:}

The researcher presented the questionnaire form in its initial form to a number of experts who are:

Professors from the colleges of sport education in the field of sports training and biological health sciences, and there are (7) in order to explore their opinion on the accuracy of the questionnaire terms, clarity and suitability for the purpose of the research.

\section{2-Honesty of the internal consistency:}

The researcher tested the validity of the questionnaire by applying it to the exploratory sample, which represents the research community and from outside the core sample and its strength is (15) reluctant to private health clubs. Verify the hypothetical composition of the questionnaire.

Second: Calculate the stability factor of the questionnaire:

Alpha kronbach coefficient values for questionnaire expression

\begin{tabular}{c|c}
\hline \hline questionnaire & Alpha \\
\hline $\begin{array}{l}\text { The role of a qualified sports } \\
\text { coach in achieving safety and } \\
\text { security goals in health clubs }\end{array}$ & 0.813 \\
\hline \hline
\end{tabular}

Through the above, the researcher designed the questionnaire form and determined the axes of each according to the research goal as follows:

\section{Survey form:}

The data collection tool included the general data of the research sample

And it was presented to a group of experts in the colleges of physical education and they number (7) with the aim of:

-Determine the degree of importance of all proposed axes to achieve the research aim.

-Adding what they deem appropriate. 
-Deleting what they deem inappropriate.

-Arranging the axes according to their importance

Table (1)

Percentage of expert opinions from the experts on the proposed themes: "Guiding signs in health clubs and their role in reducing injuries" in their initial form

\begin{tabular}{l|c|c|r}
\hline $\begin{array}{l}\text { The themes of the } \\
\text { questionnaire }\end{array}$ & $\begin{array}{c}\text { the } \\
\text { number of } \\
\text { phrases }\end{array}$ & $\begin{array}{c}\text { the number of } \\
\text { correspondents }\end{array}$ & $\begin{array}{c}\text { the } \\
\text { percentage }\end{array}$ \\
\hline $\begin{array}{l}\text { first axis: } \\
\text { tangibility }\end{array}$ & 6 & 7 & $100 \%$ \\
\hline $\begin{array}{l}\text { second axis: } \\
\text { sympathy }\end{array}$ & 5 & 7 & $100 \%$ \\
\hline $\begin{array}{l}\text { third axis: health } \\
\text { club properties }\end{array}$ & 5 & 6 & $86 \%$ \\
\hline
\end{tabular}

Illustrated in Table (1)

The percentage and weight of approval of the experts on the axes and dimensions of the questionnaire and opinions ranged between (80-100\%), and the researcher and gentlemen supervisors agreed with or more, and \%80the axes that had obtained a relative importance of thus it is clear that it was done Accept all axes.

Exploratory experience: 15

Basic experience: 50

Statistical processing:

The researcher used the statistical treatments appropriate to the nature of the research, which are: 
Relative weight, rated grade, and Cay2.

Presentation and discussion of results:

First: results:

Table (2)

Repetition, grade, relative weight, and Cay 2 responses to sample responses. Research on the phrases of the questionnaire, "Indicative signs in health clubs and their role in reducing injuries".

$(\mathrm{N}=50)$

\begin{tabular}{|c|c|c|c|c|c|c|c|c|}
\hline \multirow[t]{2}{*}{$S$} & \multirow[t]{2}{*}{ phrase } & \multirow{2}{*}{$\begin{array}{l}\text { yes } \\
R\end{array}$} & \multirow{2}{*}{$\begin{array}{l}\text { maybe } \\
\mathbf{R}\end{array}$} & \multirow{2}{*}{\begin{tabular}{|l|} 
no \\
$R$
\end{tabular}} & \multirow{2}{*}{$\begin{array}{l}\text { estimated } \\
\text { grade }\end{array}$} & \multirow{2}{*}{$\begin{array}{r}\text { relative } \\
\text { weight }\end{array}$} & \multirow[t]{2}{*}{ Cay2 } & \multirow[t]{2}{*}{ A } \\
\hline & & & & & & & & \\
\hline \multicolumn{9}{|c|}{ The first axis: tangibility } \\
\hline 1 & $\begin{array}{l}\text { The health club's } \\
\text { site is easily } \\
\text { accessible }\end{array}$ & 28 & 12 & 10 & 118 & 78.6 & 11.6 & 10 \\
\hline 2 & $\begin{array}{l}\text { All sports } \\
\text { equipment and } \\
\text { tools are available } \\
\text { inside the club } \\
\end{array}$ & 36 & 12 & 2 & 134 & 89.3 & 36.6 & 14 \\
\hline 3 & $\begin{array}{l}\text { The guide boards } \\
\text { make dealing with } \\
\text { sports equipment } \\
\text { easier }\end{array}$ & 40 & 7 & 3 & 137 & 91.3 & 49.4 & 15 \\
\hline 4 & $\begin{array}{l}\text { The health club } \\
\text { administration is } \\
\text { concerned with } \\
\text { the continuous } \\
\text { renewal of } \\
\text { equipment, sports } \\
\text { equipment and } \\
\text { guide boards }\end{array}$ & 32 & 12 & 8 & 128 & 85.3 & 21.2 & 12 \\
\hline 5 & $\begin{array}{l}\text { There are safety } \\
\text { and security } \\
\text { factors available in } \\
\text { all sections of the } \\
\text { health club }\end{array}$ & 30 & 15 & 5 & 125 & 83.3 & 19.1 & 13 \\
\hline 6 & $\begin{array}{l}\text { The health club } \\
\text { uses appropriate } \\
\text { guiding boards in } \\
\text { the corridors and } \\
\text { roads to help }\end{array}$ & 20 & 5 & 25 & 95 & 63.3 & 19.1 & 9 \\
\hline
\end{tabular}




\begin{tabular}{|c|c|c|c|c|c|c|c|c|}
\hline & $\begin{array}{l}\text { identify the health } \\
\text { club sections }\end{array}$ & & & & & & & \\
\hline \multicolumn{9}{|c|}{ The second axis: empathy } \\
\hline 7 & $\begin{array}{l}\text { I can put my full } \\
\text { confidence in the } \\
\text { health club } \\
\text { management }\end{array}$ & 29 & 11 & 10 & 119 & 79.4 & 13.7 & 11 \\
\hline 8 & $\begin{array}{l}\text { The club staff } \\
\text { understands the } \\
\text { needs of the } \\
\text { participants } \\
\text { accurately }\end{array}$ & 38 & 10 & 2 & 136 & 90.7 & 42.8 & 16 \\
\hline 9 & $\begin{array}{l}\text { The club } \\
\text { administration is } \\
\text { concerned with } \\
\text { the internal } \\
\text { atmosphere and } \\
\text { providing } \\
\text { additional services } \\
\text { and guidance } \\
\text { boards }\end{array}$ & 22 & 5 & 23 & 99 & 66 & 12.2 & 8 \\
\hline 10 & $\begin{array}{l}\text { The health club } \\
\text { management is } \\
\text { keen to present its } \\
\text { best programs, } \\
\text { devices and tools } \\
\text { to its subscribers, } \\
\text { accompanied by } \\
\text { illustrative guide } \\
\text { boards }\end{array}$ & 16 & 3 & 31 & 85 & 56.7 & 23.5 & 4 \\
\hline 11 & $\begin{array}{l}\text { The health club } \\
\text { pays appropriate } \\
\text { attention to the } \\
\text { informative and } \\
\text { illustrative boards }\end{array}$ & 20 & 3 & 27 & 93 & 62 & 18.2 & 6 \\
\hline
\end{tabular}

The third axis: the characteristics of the health club

\begin{tabular}{l|l|l|l|l|l|l|l|l}
\hline 12 & $\begin{array}{l}\text { Waiting rooms are } \\
\text { available in the } \\
\text { waiting rooms } \\
\text { indicative, } \\
\text { explanatory and } \\
\text { advertising panels }\end{array}$ & 18 & 7 & 25 & 93 & 62 & 9.8 & 5 \\
\hline 13 & $\begin{array}{l}\text { The club } \\
\text { administration is } \\
\text { keen to update } \\
\text { and constantly }\end{array}$ & 20 & 8 & 22 & 98 & 65.4 & 6.8 & 7 \\
\hline \hline
\end{tabular}




\begin{tabular}{l|l|l|l|l|l|l|l|l}
\hline \hline & $\begin{array}{l}\text { develop guidance } \\
\text { boards for devices } \\
\text { and tools }\end{array}$ & & & & & & & \\
\hline 14 & $\begin{array}{l}\text { The indicative } \\
\text { boards shall be } \\
\text { located in distinct } \\
\text { and clear places }\end{array}$ & 12 & 5 & 33 & 79 & 52.3 & 25.4 & 2 \\
\hline 15 & $\begin{array}{l}\text { The health club } \\
\text { has health } \\
\text { attachments and } \\
\text { informative signs } \\
\text { for each section of } \\
\text { the club }\end{array}$ \\
\hline 16 & 16 & 2 & 32 & 84 & 56 & 27.04 & 3 \\
$\begin{array}{l}\text { The Health Club } \\
\text { has an easy and } \\
\text { simple translation } \\
\text { of the guide } \\
\text { boards attached to } \\
\text { the equipment } \\
\text { and sports } \\
\text { equipment }\end{array}$ & 9 & 2 & 39 & 70 & 46.7 & 46.3 & 1 \\
\hline \hline
\end{tabular}

for the responses of the research There is a significance for cay2 sample in the direction of yes to the phrases numbers $(1,2,3,4,5,7,8)$ as there is no indication for cay2for the responses of the research sample for responses 2 in a direction somewhat, and there is indication for $(6,9,10,11,12,13,14,15,16)$ not in the phrases.

\section{Discussion of the results of the questionnaire on "Health club "benchmarks and their role in reducing injuries:}

It is clear from Table (2) for the responses of the same sample, the research on the phrases of the Qualified Trainer role questionnaire that the relative weight of the responses of the research sample ranged between (46.4\%-91.3\%)

It is also clear that the phrases are numbers (1.2.3.4.5.7.8) and their relative weight indicates that the level of services in the health club is good in terms of the club's location and easy access to it, the availability of all sports equipment and tools and modern equipment in clubs Health, the availability of guiding marks facilitates the possibility of dealing with sports devices, the club management is always concerned with the constant renewal of sports equipment and devices and the periodic maintenance of them, the possibility of trust in the 
management of the club because of the attention given to the views of the visitors and their needs, the understanding of health club employees and coaches to the needs Attending health clubs.

While it is clear that the phrases $(6.9 .10 .11 .12 .13 .14 .15 .16)$ their relative weight indicates the poor availability of guiding signs and the lack of interest in their presence in the corridors and roads to explain to the reluctant, and lack of attention to the internal atmosphere of the health club and Lack of providing additional services and guiding boards, lack of keenness to provide their best programs accompanied by explanatory boards, lack of interest in placing guiding signs in appropriate and distinctive places, lack of updating of guiding boards accompanying sports devices, lack of health attachments and identification guides for each One of the health club departments, not to quit Or easy and simple translation of the signs guiding devices associated with sports.

This is in line with the Tamer Hussein study (2008) to try to reach standards and foundations for formulating physical standards and internal spaces for health clubs in a manner that harmonizes the provision of basic and functional services to the individual and achieves complementarity in the units that make up the health club and provide the necessary indicative signs for the reluctant.

With this, the research questions are answered

Does the availability of indicative signs (health illustrations) in health clubs reduce the rates of injuries for the undecided?

First: Conclusions:

The level of frequent interaction with the health club management is good, and the good response of the club management enhances the confidence of the visitors on health clubs through: 
-Attention to the constant renewal and periodic maintenance of sports equipment.

-To satisfy the health and physical needs of the hesitant.

-Availability of all sports equipment needed by health club attendees.

Second: Recommendations:

-The necessity of paying attention to the presence of indicative signs for each of the health club's departments.

-The need to pay attention to translating the guiding signs attached with the devices to facilitate the process of using them by health club visitors and not to be injured by misuse or misunderstanding the work of the devices.

-The continuous and continuous technological development of the club's capabilities and the modernization of its equipment and tools.

-The need to take into account the spaces and distances between devices and tools and good ventilation to reduce injuries.

\section{References}

1-Tamer Hussein Al-Shtaihi: the basics of using agronomics and technology. Modern Health Clubs with Anthropometric Standards, Fourth International Council for Health physical Regional Conference. 
Physical Education, for Education, Recreation, Sports and Expression the Middle East Region, College of Physical Education for Boys, October 17-15Alexandria University .2008

2-Medhat Kassem, Ahmed Abdel-Fattah: Health Clubs, Arab Thought House, Cairo.2004.

3-Medhat Kassem: Health and Mathematical Sciences for Personal Coach, Dar Al-Fikr Al-Arabi. Cairo.2020.

4-Muhammad Hassan Allawi: The Psychology of Athletic Training, Dar ,Al-Fikr Al-Arabi, Cairo .2002.

5-Wajdi Mustafa Al-Fatah and Mohamed Lutfi Al-Saied: the scientific foundations of sports training. For the player and coach. Dar al-hoda for publishing and distribution. Minya.2002.

6-www.ozgurlertrafik.com.tr.

7-www.mawared.org. 
